\title{
Goiter drawing in Ulrich Boner's Der Edelstein Codices Palatini Germanici 794
}

\author{
G. Dionigi ${ }^{1}$ (1) $\cdot$ R. Dionigi ${ }^{2}$
}

Received: 15 May 2020 / Accepted: 20 May 2020 / Published online: 29 May 2020

(C) Italian Society of Endocrinology (SIE) 2020

\begin{abstract}
We provide an example of representation of thyroid swelling in the artwork of Ulrich Boner's Der Edelstein Codices Palatini Germanici 794.
\end{abstract}

Keywords Goiter $\cdot$ Endemic $\cdot$ Drawing $\cdot$ Art $\cdot$ Endocrinology

Ulrich Boner wrote a collection of fables entitled Der Edelstein ('The Jewel') (c. 1349), one hundred in number, which were based principally on those of Avianus (fourth century) and the Anonymus Neveleti (edited by Isaac Nicolas Nevelet, 1610) [1]. It was printed in 1461 at Bamberg by Albrecht Pfister and was one of the first books printed in the German language [1]. It is copiously illustrated with pen-andlink drawings [1,2]. One illustration definitely represents a man with a huge goiter (Fig. 1). Basic description of the

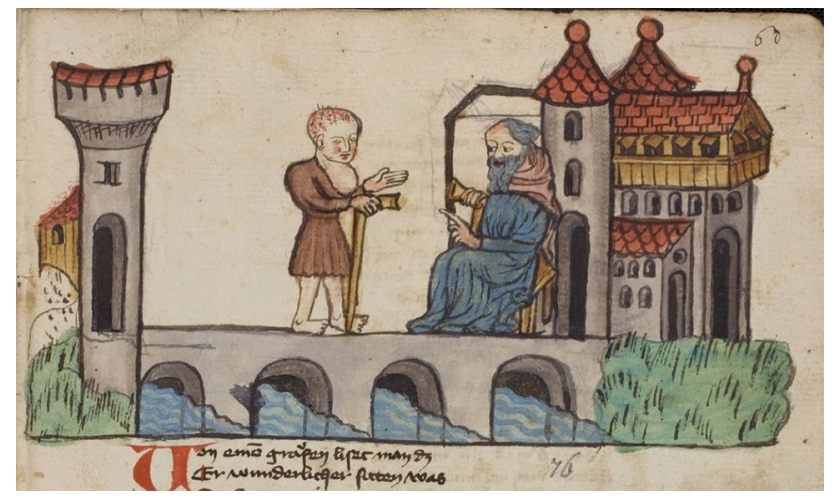

Fig. 1 Representation of thyroid swelling, intended as an enlarged anterior neck region

G. Dionigi

gdionigi@unime.it

1 Division for Endocrine and Minimally Invasive Surgery, University of Messina, Messina, Italy

2 Istituto Lombardo Accademia di Scienze e Lettere, Milano, Italy illustrations is provided by the Universitatsibibliothek Heidelberg (https://digi.ub.uni-heidelberg.de/diglit/cpg794).

Author contributions GD and RD contributed equally.

Funding None.

\section{Compliance with ethical standards}

Conflict of interest The authors declare that they have no conflicts of interest.

Ethical approval Not required.

Informed consent Not required.

\section{References}

1. Boner U (1844) Der Edelstein (in German). G. J. Göschen'sche Verhandlung, Leipzig

2. Dionigi R, Zhang D, Dionigi G (2020) Will the shepherd be able to play the alpine horn with that huge goiter (XVI century)? J Endocrinol Invest. https://doi.org/10.1007/s40618-019-01170-y

Publisher's Note Springer Nature remains neutral with regard to jurisdictional claims in published maps and institutional affiliations. 